\title{
Pengaruh Pelatihan terhadap Peningkatan Pengetahuan Kader Posyandu tentang Deteksi Dini TBC Anak di Kelurahan Tanjung Mas Semarang
}

\author{
Eti Rimawati ${ }^{1}$ Sri Handayani ${ }^{2}$, MG. Catur Yuantari ${ }^{3}$ \\ 1,2,3 Program Studi Kesehatan Masyarakat, Fakultas Kesehatan, Universitas Dian Nuswantoro \\ Email: ${ }^{1}$ eti.rimawati@dsn.dinus.ac.id, ${ }^{2}$ sri.handayani@dsn.dinus.ac.id, ${ }^{3}$ mgcatur.yuantari@dsn.dinus.ac.id
}

\begin{abstract}
Abtsrak
Gejala tuberculosis pada anak tidak secara spesifik terlihat, sehinga diperlukan upaya deteksi dini. Salah satu upaya melakukan deteksi dini adalah dengan memantau tumbuh kembang anak dalam kegiatan posyandu melalui peran kader posyandu. Tujuan dari kegiatan pelatihan ini adalah untuk meningkatkan pengetahuan kader posyandu dalam deteksi dini tuberkulosis pada anak. Metode: Sasaran pelatihan adalah 21 kader posyandu yang dipilih secara purposive sampling. Kegiatan pelatihan sebagai bentuk pengabdian masyarakat dilaksanakan dengan tahapan pemberian pretest, presentasi materi dan kasus serta soal-soal posttest. Analisis Wilcoxon Signed Rank Test digunakan untuk menentukan perbedaan pengetahuan sebelum dan sesudah pelatihan. Semua kader berjenis kelamin perempuan, dengan pendidikan terendah SLTP $(9,8 \%)$, termuda berusia 38 tahun dan tertua 65 tahun. Hasil uji beda menunjukkan bahwa ada perbedaan antara sebelum dan sesudah pelatihan ( $\mathrm{p}$ value 0,0006 ) yang menunjukkan bahwa metode pelatihan efektif dalam meningkatkan pengetahuan kader.
\end{abstract}

Kata Kunci: Kader, TBC, Deteksi Dini, Anak

\begin{abstract}
Symptoms of tuberculosis in children that are not specific require early detection efforts. One of the efforts to carry out early detection is to monitor children's growth and development in posyandu activities. Posyandu cadres have an important role in this. The purpose of this training activity is to increase the knowledge of posyandu cadres in early detection of tuberculosis in children. Method: The target of the training was 21 posyandu cadres who were selected by purposive sampling. Training activities as a form of community service are carried out with the stages of giving a pretest, presentation of material and case and posttest questions. The Wilcoxon Signed Rank Test analysis is used to determine differences in knowledge before and after training. All cadres were female, with the lowest education was junior high school (9.8\%), the youngest was 38 years old and the oldest was 65 years old. The results of the difference test showed that there was a difference between before and after training ( $p$ value 0.0006), indicating that the training method was effective in increasing the knowledge of the cadres.
\end{abstract}

Key words: Kader, TBC, early screening, child

\section{PENDAHULUAN}

Beban kasus TBC pada Anak di dunia belum dapat diketahui karena kurangnya alat diagnostik yang "child-friendly" dan tidak adekuatnya sistem pencatatan dan pelaporan kasus TBC Anak. Diperkirakan banyak anak menderita TBC yang tidak mendapatkan penanganan yang benar. Pada tahun 2017 terdapat 10 juta kasus TB di dunia dan terdapat 1,6 juta jiwa meninggal karena TBC. Diantara kasus tersebut terdapat 1 juta kasus TB anak (0-14 tahun) yang diperkirakan sekitar 7.5 juta anak terinfeksi TB setiap tahunnya. Selain itu, lebih dari 1 juta kasus baru TB Anak terjadi setiap tahun.[1].

Gejala TBC pada anak yang tidak khas, antara lain penurunan berat badan, lemah, letih, lesu. Batuk pada anak jarang merupakan gejala utama TB pada anak. Pada anak dengan gejala utama batuk dan atau 
anak dapat mengeluarkan dahak WAJIB diperiksa dahak mikroskopis SPS. Apabila terbukti anak dengan BTA positif, maka anak tersebut termasuk sumber penularan bagi lingkungan di sekitarnya. Anak $<3$ tahun dan dengan malnutrisi atau kondisi immunosupresan memiliki resiko paling tinggi untuk menderita TB. TB terutama menyerang paru, tapi $20-30 \%$ TB pada anak menyerang organ lain. Bayi dan balita paling beresiko terkena TB berat seperti meningitis TB yang mampu menyebabkan buta, tuli serta kelumpuhan. [1]

Proporsi kasus TBC Anak diantara semua kasus yang diobati di Indonesia dari 2007 sampai 2013 berkisar pada 7,9\% sampai $12 \%$. Angka ini masih berada pada batas normal proporsi kasus TBC anak diantara semua kasus. Adanya kecenderungan overdiagnosis, underdiagnosis maupun underreported kasus TB Anak karena masih adanya kesulitan mendiagnosis TB pada Anak, Anak sulit untuk berdahak, seandainya bisa berdahak belum tentu TBC pada Anak memberikan hasil BTA positif, adanya anggapan TBC Anak dianggap tidak menular sehingga belum mendapat perhatian dari masyarakat.

Gejala umum TBC anak adalah berat badan tidak naik dalam 2 bulan terakhir meskipun sudah diberikan upaya perbaikan gizi, demam lama ( $\geq 2$ minggu) dana atau berulang tanpa sebab yang jelas, batuk lama ( $\geq 2$ minggu), lesu, malaise dan kurang aktif bermain.[2]

Pada anak-anak usia 0-5 tahun, pemantauan tumbuh kembang secara periodik per bulan dilakukan melalui kegiatan pos pelayanan terpadu di tiap RW (rukun warga). Kader mempunyai peran besar dalam usaha kesehatan berbasis masyarakat in, antara lain dalam melakukan pendataan, penimbangan dan pencatatan berat badan anak. Sebagaimana salah satu gejala utama TBC anak adalah penurunan berat badan dalam 3 bulan terakhir, maka peran kader menjadi sangat penting dalam melakukan deteksi dini TBC anak. Deteksi dini akan membantu dalam penemuan kasus TBC anak yang selanjutnya akan dilakukan rujukan ke puskesmas untuk penegakan diagnosis.

Kasus TBC di Kota Semarang sampai dengan akhir Desember 2018 adalah 4.252 kasus. Bila diasumsikan proporsi kasus TBC anak adalah 7,9\%, maka diperkirakan ada 336 kasus TBC anak di Kota Semarang. Oleh karena masih tinggi kasus TBC di Kota Semarang, maka program penanggulangan TBC menjadi salah satu indicator utama program di bidang kesehatan, selain AKI, DBD dan HIV AIDS.[3]

Kader, sebagai tenaga sukarela di masyarakat ternyata masih mempunyai pengetahuan dengan nilai tentang TBC.[4] Penelitian Ita Puji Lestari (2019) menggambarkan adanya hubungan antara pengetahuan dan motivasi dengan peran kader dalam penemuan kasus TBC.[5] Sebagaimana dijelaskan dalam panduan posyandu, salah satu tugas kader adalah memantau tumbuh kembang anak melalui kegiatan di posyandu.[6] Namun, hasil Riset Kesehatan Dasar tahun 2013, terdapat peningkatan proporsi tidak dilakukannya pemantauan tumbuh kembang anak, dari 25,5\% (2010) menjadi 34,3\% (2013).[7]

Melalui kegiatan penimbangan balita oleh kader, maka dapat dilakukan deteksi lebih dini terkait adanya gejala umum TBC anak melalui pemantauan berat badan anak dalam 2-3 bulan terakhir. Aticeh masih menemukan 65,3\% kader mempunyai pengetahuan rendah dalam deteksi dini.[8]

Sebagaimana dijelaskan oleh $L W$ Green, bahwa pengetahuan merupakan faktor pemudah (predisposisi) untuk terjadinya perilaku.[9] Oleh karena itu diperlukan adanya peningkatan kemampuan kader dalam pertumbuhan dan perkembangan anak untuk mendukung deteksi dini dan penemuan kasus TBC anak di posyandu.

Experiential learning adalah proses belajar dengan menggunakan pengalaman sebagai media belajar [10]. Kader melakukan proses belajar dari pengalaman mereka melakukan penimbangan dan pencatatan tumbuh kembang anak di posyandu. Proses belajar dengan merenungkan apa yang telah dikerjakan, sangat mungkin diterapkan bagi petugas kesehatan.[11]

\section{METODE PENELITIAN}

Sasaran kegiatan pengabdian masyarakat adalah kader posyandu di Kelurahan Tanjung Mas Kota Semarang yang dipilih secara purposive sampling, sejumlah 21 orang, terdiri dari coordinator kader posyandu tingkat RW, koordinator kader posyandu tingkat kecamatan dan kader tuberkulosis. Instrumen pengetahuan terdiri dari 10 pertanyaan tentang gejala tuberkulosis anak, risiko penularan TBC Anak dan pengukuran status gizi anak melalui antropometri. Intervensi dilakukan melalui pemaparan materi tentang deteksi TBC anak, pengukuran antropometri dan cara deteksi dini TBC anak melalui hasil antropometri. 
Selanjutnya diskusi analisa kasus oleh kader posyandu. Modul panduan deteksi dini TBC anak oleh kader posyandu, menjadi alat bantu selama intervensi. Mengingat kegiatan penelitian berlangsung selama pandemi covid-19, maka kegiatan intervensi dilakukan dengan beberapa aturan protokol kesehatan, antara lain memakai masker dan face shield, menjaga jarak dan pembatasan lama waktu intervensi (pelatihan). Analisa data deskriptif disajikan dalam bentuk distibusi frekuensi, skor minimal, skor maksimal, skor ratarata, standar deviasi dan grafik perubahan skor. Pembuktian efektivitas intervensi dilakukan untuk mengetahui signifikansi perbedaan antara 2 data berpasangan berskala interval dan tidak berditribusi normal menggunakan uji beda Wilcoxon Signed Rank Test.

Tahapan kegiatan pengabdian masyarakat, dapat digambarkan sebagai berikut:

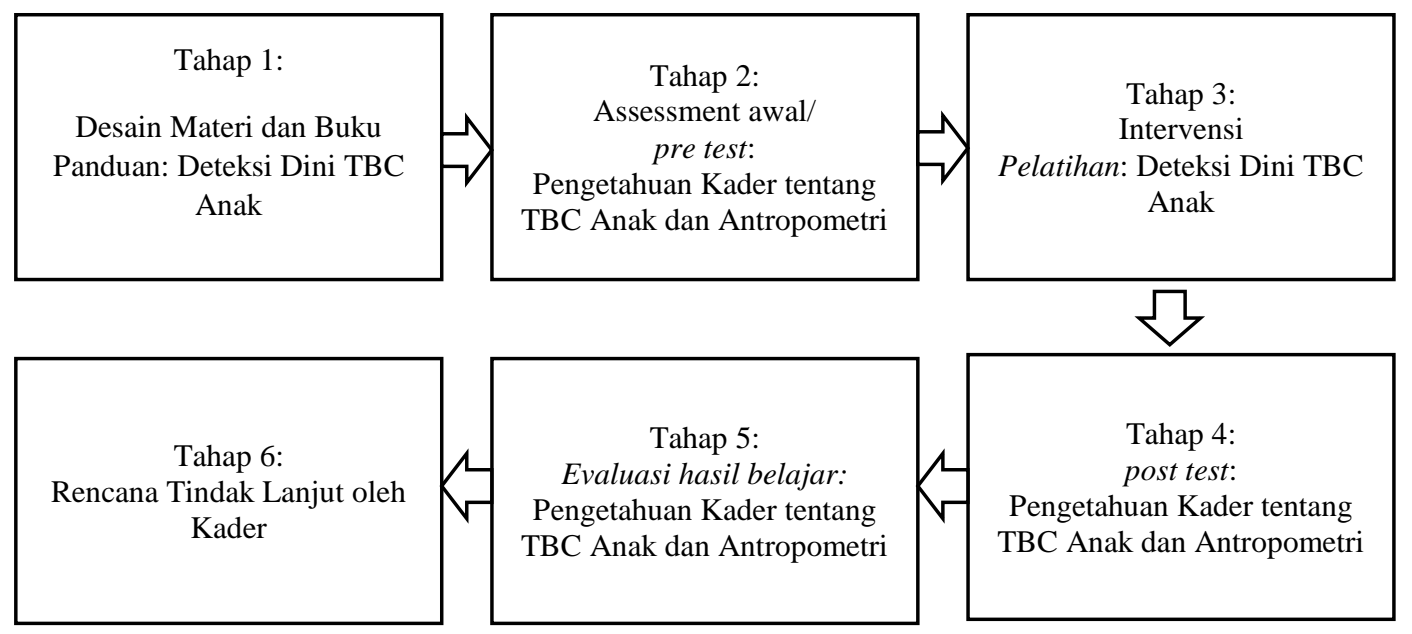

Gambar 1. Error! Reference source not found.

\section{HASIL DAN PEMBAHASAN}

Kader merupakan anggota masyarakat yang bersedia, mampu dan memiliki waktu untuk menyelenggarakan kegiatan Posyandu secara sukarela[6]. Pelatihan kader posyandu tentang deteksi dini TBC pada anak dihadiri oleh 21 kader perwakilan RT yang ada di Kelurahan Tanjung Mas. Seluruh kader posyandu berjenis kelamin perempuan dengan pendidikan tertinggi yaitu sarjana (4.8\%) dan pendidikan terendah adalah SMP (9.5\%). Jika dilihat dari tingkat pendidikan sebagian besar kader posyandu di Kelurahan Tanjung Mas memiliki pendidikan tinggi yaitu $81 \%$ telah menyelesaikan pendidikan hingga jenjang SMA. Tingkat pendidikan merupakan faktor pemudah (predisposing) untuk terjadinya perubahan perilaku[12]. 
Tabel 1. Tingkat Pendidikan Kader Posyandu

\begin{tabular}{|c|c|c|}
\hline Tingkat Pendidikan & Frekuensi & Persentase \\
\hline Sarjana & 1 & 4.8 \\
\hline Diploma & 1 & 4.8 \\
\hline SMA & 17 & 81 \\
\hline SMP & 2 & 9.5 \\
\hline
\end{tabular}

Kader posyandu Kelurahan Tanjung Mas memiliki usia yang cukup bervariasi dimana usia paling tua adalah 65 tahun dan mereka masih aktif menjadi kader posyandu. Sedangkan usia paling muda yaitu 38 tahun dengan rata-rata usia kader yaitu 48.19 tahun, Usia tidak berhubungan dengan motivasi seseorang menjadi tenaga sukarela atau kader.[13]

Tabel 2. Usia Kader Posyandu

\begin{tabular}{|c|c|c|c|c|c|}
\hline \multirow{2}{*}{ Usia } & Mean & Median & Minimum & Maximum & SD \\
\cline { 2 - 6 } & 48.19 & 47 & 38 & 65 & 6.210 \\
\hline
\end{tabular}

Dari hasil skor pretest dan posttest menunjukkan bahwa terdapat kenaikan yang signifikan pengetahuan kader tentang TBC dan deteksi dini pada balita. Dari grafik didapatkan bahwa sebagaian besar responden memiliki skor yang meningkat pada nilai posttest dibandingkan dengan nilai pretest.

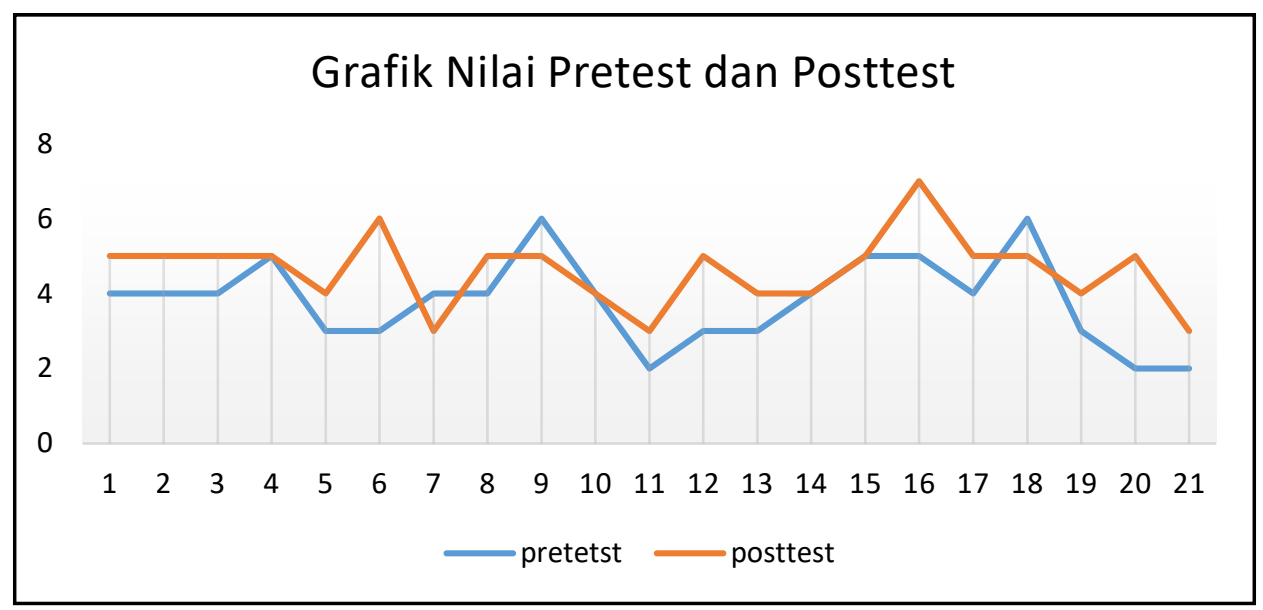

Gambar 2. Hasil Perubahan Skor Pretest dan posttest

Berdasarkan hasil uji Wilcoxon Signed Ranks test, maka dapat diperoleh hasil sebagai berikut:

Tabel 3. Uji Beda Wilcoxon Signed Ranks test

\begin{tabular}{|c|c|c|c|c|}
\hline \multicolumn{5}{|c|}{ Ranks } \\
\hline & & $\mathbf{N}$ & Mean Rank & Sum of Ranks \\
\hline \multirow{4}{*}{$\begin{array}{c}\text { total_post - } \\
\text { total_pre }\end{array}$} & Negative Ranks & $3^{\mathrm{a}}$ & 7.00 & 21.00 \\
\hline & \begin{tabular}{|l|} 
Positive Ranks \\
\end{tabular} & $14^{\mathrm{b}}$ & 9.43 & 132.00 \\
\hline & Ties & $4^{\mathrm{c}}$ & & \\
\hline & Total & 21 & & \\
\hline P-Value & & 0.0006 & & \\
\hline \multicolumn{5}{|c|}{ a. total_post $<$ total_pre } \\
\hline \multicolumn{5}{|c|}{ b. total_post > total_pre } \\
\hline \multicolumn{5}{|c|}{ c. total_post = total_pre } \\
\hline
\end{tabular}


Dari uji beda didapatkan bahwa :

1. Terdapat 3 responden yang memiliki penurunan nilai dari pre-test ke post test dengan mean rank 7.00 dan sum of rank 21.00

2. Terdapat 14 responden yang mengalami peningkatan nilai pre-test ke posttest dengan mean rank 9.43 dan sum of rank 132.00

3. Tidak ada responden yang memiliki nilai sama pada pretest dan posttest.

Berdasarkan output SPSS didapatkan bahwa nilai signifikan 0.0006 dimana terdapat perbedaan antara skor pretest dan posttest pada peserta pelatihan. Sehingga dapat disimpulkan bahwa metode pelatihan signfikan meningkatkan pengetahuan. Hasil riset juga menunjukkan bahwa ada hubungan antara pengetahuan dengan kemampuan kader dalam penemuan kasus tuberculosis. [5] Pengetahuan dan motivasi kader akan meningkatkan keaktifan kader di posyandu.[14] Motivasi diri juga mendukung inilah yang nantinya akan meningkatkan penemuan kasus aktif oleh kader [15]

\section{KESIMPULAN DAN SARAN}

Berdasarkan hasil kegiatan pengabdian masyarakat dalam bentuk pelatihan deteksi dini tuberculosis anak oleh kader posyandu, dapat disimpulkan bahwa:

1. Peserta pelatihan adalah semua koordinator kader posyandu di wilayah kelurahan Tanjung Mas, sehingga mempunyai posisi strategis untuk melakukan deseminasi hasil pelatihan kepada kader posyandu yang berada dibawah koordinasinya.

2. Peserta pelatihan, semua adalah wanita dengan pendidikan terendah adalah SMP $(9,5 \%)$ dan usia termuda 38 tahun dan usia tertua 65 tahun.

3. Setelah pelatihan terdapat peningkatan skor pre-test dengan post test.

4. Terdapat perbedaan antara skor pre-test dan post-test pada peserta pelatihan dengan nilai signifikan (p.value) 0,0006 .

Tindak lanjut dari pelatihan ini adalah transfer of knowledge dari peserta pelatihan kepada kader posyandu yang menjadi rekan kerjanya, dapat dilaksanakan dengan baik.

\section{UCAPAN TERIMA KASIH}

Ucapan terima kasih kepada Lembaga Penelitian dan Pengabdian Masyarakat Universitas Dian Nuswantoro Semarang atas dukungan pendanaan dalam kegiatan ini.

\section{DAFTAR PUSTAKA}

[1] Kementerian Kesehatan Republik Indonesia, “TB Anak,” 2019. https://www.tbindonesia.or.id/page/view/20/tb-anak (accessed Apr. 16, 2020).

[2] Kementerian kesehatan RI, Buku TB anak. 2016.

[3] Dinas Kesehatan Kota Semarang, "Laporan Kasus Tuberkulosis Kota Semarang," Semarang, 2019.

[4] A. Y. Megawati 1, Suriah2, Rusli Ngatimin3, "Pulmonary Tb Education on Knowledge and Attitude of Posyandu Ca- Dre Through Simulation Game of Monopoly," Media Publ. Promosi Kesehat. Indones. Indones. J. Heal. Promot., vol. 1, no. 1, pp. 5-11, 2018.

[5] I. P. Lestari and A. Tarmali, "Faktor-Faktor yang Berhubungan dengan Peran Kader dalam Penemuan Kasus Tuberkulosis BTA Positif di Kabupaten Magelang," J. Healthc. Technol. Med., vol. 5, no. 1, pp. 1-12, 2019, [Online]. Available:

http://www.jurnal.uui.ac.id/index.php/JHTM/article/view/314/100.

[6] Kementerian Kesehatan RI, Pedoman Umum Pengelolaan Posyandu. 2011.

[7] K. K. B. P. dan P. K. 1, "Hasil Utama Riset Kesehatan Dasar," Kementrian Kesehat. Republik 
Indones., pp. 1-100, 2018, doi: 1 Desember 2013.

[8] S. S. Aticeh, Maryanah, "Pengetahuan Kader Meningkatkan Motivasi dalam Melakukan Deteksi Dini Tumbuh Kembang Balita," J. Ilmu dan Teknol. Kesehat., vol. 2, no. 2, pp. 71-76, 2015.

[9] L. W. Green, "Modifyng and Developing Behavior," Annu. Rev. Public Health, vol. 5, pp. 215236, 1984.

[10] Fathurrohman, Model-Model Pembelajaran Inovatif. Yogyakarta: Ar-Ruzz Media, 2015.

[11] P. Burnard, Teaching Interpersonal Skills: A Handbook of Experiential Learning for Health Professionals. Springer, Science+Bussiness, 1990.

[12] L. W. Green, M. W. Kreuter, and L. W. Green, Health program planning : an educational and ecological approach. McGraw-Hill, 2005.

[13] M. A. Okun and A. Schultz, "Age and motives for volunteering: Testing hypotheses derived from socioemotional selectivity theory," Psychol. Aging, vol. 18, no. 2, pp. 231-239, 2003.

[14] H. A. Nugroho and D. Nurdiana, "Hubungan Antara Pengetahuan dan Motivasi Kader Posyandu dengan Keaktifan Kader Posyandu di Desa Dukuh Tengah Kecamatan Ketanggungan Kabupaten Brebes," Fikkes J. Keperawatan, vol. 2, no. 1, pp. 1-8, 2008.

[15] S. Handayani and L. Aryani, "Self Efficacy dan Self Motivation Kader dalam Melakukan Active Case Findig untuk menurunkan Epidemi Tuberkulosis dalam Mewujudkan Target SDGs 2030," VISIKES, J. Kesehat. Masy., vol. 16, no. 1, pp. 30-37, 2017. 